\title{
Bone Morphogenetic Proteins in Craniofacial Surgery: Current Techniques, Clinical Experiences, and the Future of Personalized Stem Cell Therapy
}

\author{
Kristofer E. Chenard, ${ }^{1}$ Chad M. Teven,, ${ }^{1}$ Tong-Chuan He, ${ }^{2}$ and Russell R. Reid ${ }^{1}$ \\ ${ }^{1}$ Laboratory of Craniofacial Biology and Development, Section of Plastic and Reconstructive Surgery, \\ University of Chicago Medical Center, 5841 South Maryland Avenue, MC 3079, Chicago, IL 60637, USA \\ ${ }^{2}$ Molecular Oncology Laboratory, Department of Surgery, University of Chicago Medical Center, \\ 5841 South Maryland Avenue, MC 3079, Chicago, IL 60637, USA \\ Correspondence should be addressed to Russell R. Reid, rreid@surgery.bsd.uchicago.edu
}

Received 16 June 2012; Accepted 16 October 2012

Academic Editor: Ji Wu

Copyright (C) 2012 Kristofer E. Chenard et al. This is an open access article distributed under the Creative Commons Attribution License, which permits unrestricted use, distribution, and reproduction in any medium, provided the original work is properly cited.

Critical-size osseous defects cannot heal without surgical intervention and can pose a significant challenge to craniofacial reconstruction. Autologous bone grafting is the gold standard for repair but is limited by a donor site morbidity and a potentially inadequate supply of autologous bone. Alternatives to autologous bone grafting include the use of alloplastic and allogenic materials, mesenchymal stem cells, and bone morphogenetic proteins. Bone morphogenetic proteins (BMPs) are essential mediators of bone formation involved in the regulation of differentiation of osteoprogenitor cells into osteoblasts. Here we focus on the use of BMPs in experimental models of craniofacial surgery and clinical applications of BMPs in the reconstruction of the cranial vault, palate, and mandible and suggest a model for the use of BMPs in personalized stem cell therapies.

\section{Introduction}

Critical-size osseous defects cannot heal without surgical intervention and pose a significant challenge to craniofacial reconstruction following infection, trauma, tumor, or congenital disease. Autologous bone remains the current gold standard source of donor tissue for the surgical repair of critical-size craniofacial defects; however, reconstruction of these defects is often limited by a potentially inadequate supply of bone for autograft [1-3]. Autografts from the iliac crest, ribs, tibia, or other sites are limited in supply and can incur significant donor site morbidity in $8-10 \%$ of patients [2, 4-13]. Calvarial bone grafting is considered the gold standard for repair of craniofacial defects, and data both from experimental animals and clinical experiences have demonstrated that intramembranous bone grafts such as those from the calvarium undergo less resorption than grafts from endochondral bone sites do [14]. Furthermore, the harvest of calvarial split-thickness bone grafts is associated with minimal donor site morbidity [7, 11-14].
Craniofacial reconstruction may be even more difficult in the pediatric patient because sources of bone for autograft are especially limited in children. Prior to two years of age, a child's dura mater has significant capacity for reossification of the calvarium; after two years of age, it loses its propensity to induce significant reossification of overlying bone defects [15-17]. In addition, in the case of pediatric patients, calvarial bone grafting is not a viable option until the child is six to ten years old, when the skull is developed enough to tolerate split-thickness bone grafting [2, 3, 15-19]. The most common morbid complication of autograft is bone pain at the donor site, but these complications can also potentially include hematoma, infection, chronic pain, nerve damage, and unanticipated fracture $[1,5,6,18]$.

Allogenic implants such as demineralized or cadaveric bone and alloplastic bone substitute materials such as hydroxyapatite cement, methyl methacrylate, ceramics, titanium, and porous polyethylene have also been used for the reconstruction of craniofacial defects [30,31]. Reconstruction of bony defects with alloplastic substances has been 
shown to facilitate osseous healing in a wide variety of orthopedic, neurosurgical, and craniofacial surgical scenarios by facilitating the migration of bone-forming cells into different types of scaffolds [32, 33]. However, several complications and adverse outcomes are feared and have been reported with the use of alloplastic and allogenic bone substitutes. These risks include graft infection, induction of an immune response, and transmission of infectious disease [32, 33]. For example, Wong et al. found that $59 \%$ of pediatric patients treated with hydroxyapatite cement for craniofacial repairs ultimately had infectious complications within the following year [34]. A major drawback of these agents is their inability to mediate osteoinduction and their failure to incorporate into surrounding normal bone (osseointegration). Thus, further evaluation of the safety and efficacy of these materials is warranted.

Alloplastic materials have been used alone and in conjunction with osteoprogenitor cells, as well as with bone morphogenetic proteins (BMPs) to facilitate bone regeneration [32]. BMPs have been proven to be important mediators of bone formation involved in the regulation of differentiation of osteoprogenitor cells into osteoblasts [35-43]. BMPs can be used to drive in vitro, in vivo, and ex vivo differentiation of adult-derived osteoprogenitor cells into bone-forming osteoblasts, and investigation into different conditions of BMP stimulation may provide insight into the means of achieving optimally effective bone tissue generation [43].

While BMPs hold great promise for craniofacial reconstruction, significant concern has been generated over the safety of the currently commercially available forms of recombinant human BMPs (rhBMPs) rhBMP-7 and rhBMP2 due to reports of clinically significant operative site edema in craniomaxillofacial and spinal applications [29, 44-50]. The effects of direct application of exogenous BMPs to bone defects may also prove to be too unpredictable for clinical use. Certain studies in experimental animals have shown that BMPs may actually inhibit bone formation in vivo, and the application of rhBMP to the repair of the human spinal column has been shown to be associated with resorption of vertebral bodies in certain cases $[51,52]$. Thus, future therapies involving the implantation of osteoblastic cells differentiated ex vivo from mesenchymal stem cells by exposure to BMPs may prove to be the safest and most efficacious mode of therapy.

\section{Bone Morphogenetic Proteins (BMPs)}

Bone morphogenetic proteins belong to the transforming growth factor $\beta$ (TGF- $\beta$ ) superfamily of structurally related dimeric disulfide-linked receptor ligands [53-57]. The TGF$\beta$ superfamily includes proteins involved in the regulation of organismal development, cell differentiation, cell growth, and cell proliferation [55]. They are expressed by most cells in the body, and alterations in expression are implicated not only in normal biological processes such as organogenesis, embryogenesis, fracture healing, and wound healing, but also in pathological states including cancer, atherosclerosis, fibrotic diseases, and developmental diseases [54, 58].
Cranial neural crest cells are responsible for the formation of the craniofacial skeleton via intramembranous ossification, the process whereby mesenchymal cells directly differentiate into osteoblasts to form intramembranous flat bones. Intramembranous ossification occurs without the intermediate development of a cartilaginous scaffold seen in endochondral ossification of the axial and limb skeletons. The axial and limb skeletons are embryonically derived from paraxial mesoderm and lateral plate mesoderm cells, respectively, in contradistinction to the derivation of the craniofacial skeleton from neural crest cells. The osteogenic differentiation of craniofacial neural crest cells in normal development relies on signaling interactions with the overlying epithelium and includes a large number of extracellular matrix molecules, transcription factors, and cytokines including bone morphogenetic proteins $[59,60]$. The diversity of function and expression of bone morphogenetic proteins and other growth factors may be responsible for the differences in architecture and morphogenesis of bone at different locations in the vertebrate skeleton [61].

Bone morphogenetic proteins were first identified as proteins capable of inducing de novo cartilage and bone formation in vivo following subcutaneous implantation [6165]. Initially the formation of ectopic bone in early experimental models was ascribed to unknown properties of demineralized bone. Later these results were shown to have been caused by the presence of BMPs in the demineralized bone matrix $[62,66]$. BMPs have since been shown to play many other roles in vertebrate development, including morphogenic signaling in gastrulation, patterning of the vertebrate embryonic body plan along the dorsal-ventral axis, limb patterning and development, and development of the nervous system, kidneys, lungs, heart, gut, teeth, skin, and gonads [59, 67].

\section{Mechanism of Bone Morphogenetic Protein Induction of Osteogenesis}

Ligand-receptor interaction in the TGF- $\beta$ superfamily is initiated by the formation of a heterodimeric serine-threonine kinase receptor complex [68-73]. BMP signaling is transduced primarily by interaction with the BMP type I receptors ALK-2, -3, -4, and ALK-6 [74, 75] (Figure 1). The close proximity of the constitutively active type II receptor kinase to the type I receptor in the heterodimeric BMP receptorligand complex permits phosphorylation and activation of the type I receptor kinase, resulting in an active complex that initiates signal transduction in the cell $[68,71]$. The ligandreceptor interaction leads to the downstream activation of at least two distinct signal transduction pathways: the canonical Smad-mediated pathway and the noncanonical p38 mitogenactivated protein kinase pathway (MAPK) [76-79].

In the canonical Smad-mediated pathway, the activated type I receptor kinase phosphorylates receptor regulated Smad proteins (R-Smads) [68, 80]. The interaction of RSmads with membrane-bound BMP receptors is highly specific, and the R-Smads 1, 5, and 8 are recognized and phosphorylated specifically by BMP-activated ligand-Ser/Thr kinase receptor complexes [71]. The phosphorylation of 




Figure 1: The canonical Smad-mediated and Smad-independent p38 MAPK pathways for BMP signal transduction are shown. In the Smad-mediated pathway, the activation of the BMP receptor complex by BMP ligand interaction leads to phosphorylation of R-Smads 1,5 , and 8 , freeing them from the internal surface of the cell membrane. This enables the interaction between R-Smads and Co-Smad proteins, subsequently resulting in exposure of nuclear import sequences that permit the heteromeric complexes to enter the nucleus and activate transcription of osteogenic genes Dlx5, Osterix, and Runx2. In the Smad-independent pathway phosphorylation of TAK1 by the BMP ligand-receptor complex leads to signal transduction through the p38 MAP kinase pathway, resulting in transcription of Runx2.

$\mathrm{R}$-Smads results in the destabilization of $\mathrm{R}$-Smad protein complexes at the inner surface of the cell membrane, releasing R-Smads into the cytoplasm [74, 80, 81]. The release of R-Smads into the cytoplasm permits their binding to the common-partner Smad (Co-Smad) Smad 4 [71, 82]. Smad 4 is the only Co-Smad yet identified in mammalian species and is used for signal transduction by all members of the TGF$\beta$ family; thus, the binding of different R-Smads to Smad 4 is critical for determining the specificity of the different signal transduction pathways in the TGF- $\beta$ superfamily [74]. R-Smads and Smad 4 can act as transcription factors independently or when complexed as heteromers; however, Smads have the greatest effect on transcriptional regulation when R-Smads are bound to Smad 4 as heteromeric complexes $[68,71,83]$. The interaction between the RSmad and Co-Smad proteins maximally exposes the nuclear import sequences present on the R-Smad proteins, leading to increased sequestration of Smad heteromers in the nucleus $[53,71]$. Thus, the BMP ligand-receptor signal cascade permits binding of activated R-Smads 1, 5, or 8 to Smad 4 , resulting in the formation of heteromeric R-Smad-Smad4 complexes that are subsequently transported to the nucleus $[69,70,83]$.

Once in the nucleus, Smad heteromers are involved in the regulation of osteogenic gene transcription, most importantly through the transcription of the osteogenic master gene Runx2 and its transcriptional coactivators Dlx5 and Osterix [84-86]. BMP signal transduction increases differentiation-stage appropriate expression levels of major markers of osteoblastic differentiation, including the early marker CTGF, early to middle-stage markers alkaline phosphatase (ALP) and Runx2, and late-stage markers Osteopontin and Osteocalcin [39, 87-90]. The transcription factors Osterix, Dlx5, and Msx2 are critically involved in the mediation of the osteogenic effects of BMPs, and the homozygous knock-out conditions of Osterix, Msx2, and Dlx5 in mice have all resulted in significant impairment of osteogenesis [86]. While these transcription factors genes are downstream targets of Runx2 signal transduction pathways and share many of the same downstream activation effects as Runx2, they also can activate different osteogenic genes independently from Runx2 [86]. Runx2 (also known as AML3, CBfa1, and PEBP2A1) remains the critical final master gene target of both TGF- $\beta$ and bone morphogenetic protein signal transduction pathways $[78,84]$. Runx2 induces osteoblastic differentiation and is required for endochondral ossification, intramembranous ossification, and tooth development [77, 91]. Homozygous deletion of Runx 2 in mice completely inhibits ossification and is fatal immediately after birth [92, 93]. Heterozygous mutations of Runx2 are thought to produce some cases of the autosomal dominant disease cleidocranial dysplasia, a disease characterized by numerous skeletal abnormalities [79]. Runx2 is essential for the generation of an osteoblastic phenotype, as evidenced by the 
failure of Runx2-deficient calvarial cells to differentiate into osteoblasts when stimulated with BMP-2, with stimulation instead causing the generation of hypertrophic chondrocytes [94].

Runx2 is also a final target of the Smad-independent BMP and TGF- $\beta$ signal transduction pathways [84]. TGF- $\beta$ activation kinase (TAK1) is also phosphorylated and activated by the Ser/Thr kinase type I receptor subunit, initiating a kinase cascade acting through MKK3 and MKK6, mediating the phosphorylation and activation of p38 mitogen-activated protein kinase [85]. The activation of p38 MAPK ultimately results in transcription of Runx2, a point of convergence for the canonical Smad-dependent pathway and the noncanonical Smad-independent pathway in both TGF- $\beta$ and BMP signaling $[84,85]$.

BMP-2-induced expression of osteogenic differentiation markers has further been shown to be mediated differentially not only by the p38 MAP kinase system but also by extracellular signal regulated kinase (ERK) signal transduction, thus indicating that BMP signal transduction is not limited solely to the Smad-dependent and p38 MAPK signal transduction pathways $[84,95]$. Further studies have also demonstrated that there is significant crosstalk between the signal transduction pathways of the BMPs and the signaling pathways of $\mathrm{Wnt} / \beta$-catenin and IGF-1, known inducers of osteogenesis [87]. Interaction with the $\mathrm{Wnt} / \beta$-catenin pathway in particular influences osteogenesis via the RANK/OPG axis by increasing expression of osteoprotegerin and decreasing expression of RANKL, resulting in decreased osteoclastogenesis and increased bone formation [96].

\section{BMP Expression in Bone Defects}

Endogenous bone morphogenetic protein expression in fracture sites has been shown to be crucial for the initiation and progression of fracture healing in vivo [97]. Conversely, the overexpression of the native BMP antagonists Noggin and Gremlin has been shown to impair bone formation and fracture healing both in vivo and in vitro by reducing BMP activity [98-100]. Overexpression of Noggin in mice impairs osteoblastic differentiation and expression of markers of osteogenic differentiation and results in a net loss of bone density, decrease in rate of bone formation, and increase in fractures without an increase in osteoclast formation [98, 100]. Similar studies of overexpression of Gremlin demonstrated reduced bone volumes, a decreased response of boneforming cells to BMPs- and an increase in the rate of fractures [99].

Additional studies of limb fracture healing in a limb-specific BMP-2-deficient mouse model suggest that even in the presence of additional osteogenic factors, BMP-2 is necessary for the initiation of fracture healing [101]. In the complete absence of BMP-2 expression in nullizygous mouse limbs, bones are completely incapable of initiating a regenerative response to fracture, and a dose-dependent decrease in bone density is seen in BMP-2 heterozygotes [101].

Studies of BMP expression in fractures of the craniofacial skeleton also confirm involvement of BMPs in the native craniofacial fracture healing process. BMP activity, along with the activity of other members of the TGF- $\beta$ superfamily and postreceptor signaling through Smad proteins, has been shown to be elevated in native craniofacial fracture healing by intramembranous ossification during distraction osteogenesis of the mandible in rats and sheep following osteotomy [102-104].

Along with other previous well-described findings concerning the osteogenic properties of BMPs, findings such as these have suggested that the additional exogenous application of BMPs may augment the natural role of intrinsically secreted BMPs in producing osteogenesis in the setting of fracture or reconstruction of the craniofacial skeleton. Numerous animal studies have explored this possibility [102-104].

\section{Roles of the Bone Morphogenetic Proteins in Osteogenic Differentiation}

Most studies of osteogenesis using bone morphogenetic proteins have focused on BMP-2 and BMP-7, likely as a result of the commercial availability of recombinant human forms (rhBMP-2 and rhBMP-7) and their clinical applications in nonunion fracture healing and spinal fusion $[40,88]$. Though commonly used in research and clinical applications, BMP-2 and BMP-7 had not been previously proven to be the most potent inducers of osteogenesis in the BMP family prior to their adoption in clinical and research settings [105]. The creation of recombinant adenoviruses for the 14 different BMPs (AdBMPs), many of which had previously been unavailable for research use due to a lack of a recombinant or bioactive recombinant form, has resulted in a better understanding of the osteogenic potential of the different subtypes [43, 105].

In vitro and in vivo studies of AdBMP-transfected mesenchymal stem cells confirmed the osteogenic potential of BMP-2, 4, 6, 7, and 9 [43]. Studies of BMP-3 in knock-out mice had previously demonstrated that the knock-out condition resulted in an increase in bone density, demonstrating its role as a negative regulator of osteogenesis [106]. Current evidence suggests that BMPs 4 and 7 are the weakest of the osteogenic inducers of ossification in the BMP family and BMPs 2, 6, and 9 are the strongest $[41,43]$. BMP-9, one of the least studied members of the BMP family, is the most potent overall and is the strongest inducer of osteogenesis both in vitro and in vivo [40, 42, 88, 107].

Interestingly, BMP-9-induced osteogenic differentiation, unlike the osteogenic differentiation induced by the other osteogenic BMPs $(2,4,6$, and 7), has been shown to be unimpaired by the presence of BMP-3 [37, 40, 43, 89]. This finding may indicate that in addition to being the most potent inducer of bone formation, BMP-9 may also induce osteogenesis and osteogenic differentiation of mesenchymal stem cells through a signaling pathway, that is, overlapping, but also distinct from the signaling pathways shared by the other osteoinductive BMPs. Additional evidence supports this theory, as BMP-9 has been shown to have a relatively lower affinity for the BMPR-IA receptor utilized by other osteogenic BMPs [108, 109]. Further evidence which could explain the unique characteristics of BMP-9 is the presence 
of a retained N-terminal region not found in other secreted BMPs or other members of the TGF- $\beta$ superfamily; this feature has been postulated to provide increased stability to BMP-9 following secretion $[87,109]$. While BMP-9 has great promise for use in clinical and experimental scenarios, its safety for clinical use has not yet been established. Further studies not only into the safety of BMP-9 but also the mechanism and normal function of BMP-9 in osteogenesis are warranted.

\section{The Use of BMPs in Experimental Models of Craniofacial Defects}

Numerous studies of critical-size calvarial, alveolar, and mandibular defect models of BMP-induced osteogenesis have demonstrated a successful result in a wide variety of animal models. These have focused on the delivery of BMPs, typically rhBMP-2 and rhBMP-7, with a wide variety of delivery systems including demineralized bone matrix and other alloplastic materials along with the standard commercially available collagen sponge implants $[15,94,110-120]$.

A recent study by Hassanein et al. describes the comparative analysis of rhBMP-2, split thickness calvarial bone grafts, and calvarial particulate bone grafts for the repair of calvarial defects in rabbits [110]. The study authors used these grafts to repair $17 \times 17 \mathrm{~mm}$ parietal bone defects and found no significant differences in defect coverage between experimental groups; however, rhBMP-2-repaired defects produced thinner bone than both split thickness calvarial and calvarial particulate bone grafts [110]. There was no difference in bone regenerate thickness between split thickness and particulate bone grafts [110].

Skull bone regeneration of critical-size defects using rhBMP-2 has also been achieved in nonhuman primates. In a study by Takahashi et al., biodegradable hydrogels were used to deliver rhBMP-2 to a defect site created in cynomolgus monkeys and were found to be capable of inducing repair even at low doses. As the native bone bridges the gap, the hydrogel is degraded and releases BMP. The bone regenerators were not compared to autologous bone grafts but were compared to insoluble bone matrix containing rhBMP2 , and the biodegradable hydrogels were found to induce greater bone regeneration [121]. These findings suggest that the use of a delivery system that mimics the natural release of BMP in native fracture healing for exogenous administration of BMPs may yield enhanced bone regeneration.

Of particular note for pediatric craniofacial reconstruction in the calvarium, rhBMP-7 implantation has been evaluated in a growing bone model of critical-size calvarial defects in infant mini-pigs [118]. Four months after the experimental, period both the control group (autologous bone graft) and the experimental group (rhBMP-7) demonstrated equivalent histologic quality of bone regeneration and the regenerated bone maintained the structure, density, and growth expected of the native calvarium in the area of the defect. These findings suggest that BMPs may provide a good solution for craniofacial defects in the growing pediatric skeleton.

A notable study also examines the ability of BMPs to regenerate bone in the unfavorable setting of irradiated tissue. Patients requiring mandibular resection for head and neck cancer often face the additional challenge to reconstruction posed by healing and tissue regeneration in the setting of a therapeutically irradiated site. The expression levels of BMP-2 and BMP- 4 have been shown to be decreased in experimentally irradiated bone [122]. Subsequent experimental application of BMP-2 to the mandibles of rats in an irradiated bone model has been shown to provide regeneration equivalent to that of nonirradiated tissue following mandibular resection [123]. These results suggest that a significant obstacle to bone tissue regeneration in an irradiated site may be reduced levels of local BMP expression and secretion and suggest a possible role for BMP therapy in patients following radiation therapy for head and neck cancers.

\section{BMP-Induced Inflammation in Experimental Models}

In addition to human clinical reports of BMP implantassociated edema, BMP-induced inflammation has also been observed in rodent models of soft tissue inflammation in response to exogenous BMP application [46, 47]. MRI measurements of tissue edema volumes following administration of high doses of rhBMP-7 and rhBMP-2 showed that rhBMP-7 produced an inflammatory response than rhBMP2 implants in the same setting $[46,47]$. The tissue inflammation was also shown to be reduced when the rhBMPs were delivered in the presence of bone morphogenetic protein binding peptide, which functions as a slow release carrier for the BMPs in experimental models [46]. These findings suggest that under the appropriate conditions for BMP delivery, the adverse inflammatory responses may be abated.

\section{Clinical Use of BMPs in the Human Craniofacial Skeleton}

Some of the earliest reports of the clinical use of BMPs partially purified from bovine bone describe successful application of these BMPs along with titanium implants or lyophilized cartilage in the reconstruction of various craniofacial deformities found the in Apert and Crouzon syndrome [124, 125]. Commercially available rhBMP-2 is only FDA approved for intraoral applications in the craniofacial skeleton; however, off-label use of rhBMP-2 and rhBMP-7 has been attempted in some cases to solve other particularly significant reconstructive challenges in the craniomaxillofacial skeleton $[29,48,126,127]$. Notable cases in the craniomaxillofacial skeleton involve the reconstruction of the cranial vault, the reconstruction of alveolar cleft deformities, and the reconstruction of mandibular defects.

\section{9. rhBMP-2 for Human Cranial Vault Reconstruction}

The first and only reported off-label use of rhBMP-2 for cranial vault reconstruction in the medical literature is a case report from the Washington University in Saint Louis that describes reconstructions of the cranial vault using 
rhBMP-2 in pediatric patients and a subsequent notable case of adverse scalp and facial edema that required surgical discontinuation of the graft [48]. The authors describe the occasional off-label clinical use of rhBMP-2-infused collagen sponge implants in children older than 18 months of age with significant cranial defects created during cranial reconstruction procedures that would otherwise need to be repaired by autologous bone tissue grafting. Postoperative scalp, periorbital, and facial edema following surgical craniosynostosis correction usually resolves at the conclusion of the first postoperative week [48]. In the case described, a patient undergoing craniofacial reconstruction for metopic craniosynostosis experienced marked scalp, periorbital, and facial edema extending to the anterior cervical region without compromise of the patient's airway. A one-week glucocorticoid taper was used to successfully reduce the swelling until the patient's discharge; however, upon discontinuation of the steroid course on post-operative day 7 , the patient redeveloped scalp and facial edema. The patient's collagen sponge rhBMP-2 implants were removed surgically on postoperative day 10 and the swelling rapidly remitted and did not return. These results corroborate findings of adverse events related to tissue swelling and edema in previously documented case reports of rhBMP-2 use in the cervical spine, where the regional anatomical risk of adverse patient outcomes related to potentially fatal airway edema is significantly greater than that in the craniofacial region $[49,50]$.

\section{0. rhBMPs for the Reconstruction of Human Clefts}

A number of clinical studies and randomized controlled trials have demonstrated effective repair of congenital human alveolar clefts by the use of exogenously applied rhBMP, and a review of the literature is available on this subject [2025, 128] (Table 1).

The earliest reported cases of rhBMP application to bony cleft repair from Carstens et al. and Chin et al. at Saint Louis University document successful repair of congenital facial clefts with rhBMP-2. In the Chin et al. case series, 50 clefts were repaired with rhBMP-2 in 43 patients with successful clinically assessed reconstruction achieved in 49 of 50 clefts; however, radiographic evidence of repair was not provided in this study and several severe cases were additionally treated with distraction osteogenesis [20]. The Carstens et al. study describes a more complicated case where a complete cleft and mandibular defect were repaired by application of distraction assisted in situ osteogenesis (DISO) and rhBMP-2; a collagen sponge saturated with rhBMP-2 was implanted following DISO to generate new bone which was used to repair the cleft and form new bone to graft onto the deformed mandible [21]. Later, a 2009 retrospective cohort study, also from Saint Louis University, assessed the off-label use of rhBMP-2 in seventeen clefts six months postoperatively using spiral CT [24]. Sixteen of seventeen cleft repairs were found to have both vertical and transverse filling of the maxillary cleft by new bone at six months by spiral CT evaluation [24].

In 2007 Herford et al. reported a retrospective review of twelve patients undergoing cleft repair, with ten patients receiving rhBMP-2 collagen sponges and two patients receiving autologous iliac bone grafts [22]. Radiographic evaluation at four months was performed via computed tomography (CT) and showed significant development of bone in eight out of ten patients in the experimental group with two of those eight patients having significantly less bone formation than the group average [22]. On average, bone volume generation was found to be slightly less (7\%) in the rhBMP-2 treatment group than in the ABG group. Significant postoperative swelling was noted by the authors in the rhBMP-2 experimental group [22].

A 2009 study by Dickinson et al. describes the randomization of skeletally mature unilateral cleft patients with alveolar defects to experimental groups using either autologous iliac bone grafting or an rhBMP-2 prepared resorbable collagen matrix following preoperative orthodontic maxillary expansion. CT evaluation of bone formation in both groups at 12 months showed that the rhBMP-2 group had greater volume of the defect filled (93\%) when compared to the autologous iliac bone graft group (63\%) [23]. The ABG control group also had significantly greater length of stay, cost, more wound healing problems, and increased pain as a result of the donor site graft harvest [23]. These findings are unique to this study and suggest that skeletally mature patients undergoing cleft repair may have better outcomes with the use of rhBMP-2 than autologous bone grafting; these findings warrant further investigation due to the small sample size of this study.

In 2011 Alonso et al. reported the use of resorbable collagen matrix with rhBMP-2 or iliac crest ABG in a randomized controlled trial for the repair of unilateral cleft lip and palate in skeletally immature 8-12-year-old patients following preoperative orthodontic maxillary expansion [25]. Average bone volume measured by CT was found to be slightly less $(5.8 \%)$ in the rhBMP-2 treatment group when compared to the ABG group, but good outcomes were achieved in both experimental groups [25]. Significant postoperative swelling was reported in the experimental group only with $37.5 \%$ of patients experiencing this effect [25].

\section{1. rhBMPs for Human Mandibular Reconstruction}

Several clinical cases describing the use of rhBMPs for the reconstruction of human mandibular defects have been reported in the past decade $[4,26,29,44,126,129-131]$ (Table 2).

The first reported human clinical application of bone morphogenetic protein to reconstruction of the mandible was the successful reconstruction of a $6 \mathrm{~cm}$ mandibular defect by application of a poloxamer-based gel containing bone morphogenetic proteins isolated and partially purified from allogenic bone samples [26]. Radiographic confirmation of bone formation was performed at three and nine months, and a bone biopsy at nine months provided histological confirmation of the formation of bone containing healthy osteocytes.

In 2002, clinicians at the same institution performed a randomized controlled trial for the reconstruction of 
TABLE 1: Selected clinical studies using rhBMPs for human cleft reconstruction.

\begin{tabular}{|c|c|c|c|}
\hline Authors & Year & Description & Main findings \\
\hline Chin et al. [20] & 2005 & $\begin{array}{l}\text { Case series using rhBMP-2 in } 50 \\
\text { clefts, } 43 \text { patients }\end{array}$ & $\begin{array}{l}\text { Successful clinical reconstruction in } 49 / 50 \text { clefts; no } \\
\text { radiographic evidence provided; several cases treated with } \\
\text { distraction osteogenesis }\end{array}$ \\
\hline Carstens et al. [21] & 2005 & $\begin{array}{l}\text { Case report using rhBMP- } 2 \text { in } \\
\text { one patient }\end{array}$ & $\begin{array}{l}\text { Distraction assisted in situ osteogenesis followed by rhBMP- } 2 \\
\text { collagen sponge implantation; new bone in cleft site used to } \\
\text { graft onto and reconstruct deformed hemimandible }\end{array}$ \\
\hline Herford et al. [22] & 2007 & $\begin{array}{l}\text { Retrospective review using } \\
\text { rhBMP-2 }(n=12)\end{array}$ & $\begin{array}{l}\text { Significant filling of maxillary cleft by new bone in eight out } \\
\text { of ten patients in the rhBMP- } 2 \text { experimental group at four } \\
\text { months on CT }\end{array}$ \\
\hline Dickinson et al. [23] & 2008 & $\begin{array}{l}\text { Randomized controlled trial } \\
\text { using rhBMP-2 }(n=21)\end{array}$ & $\begin{array}{l}\text { Cleft repairs of skeletally mature patients found to have } \\
\text { greater volume of defect filled by new bone measured by CT } \\
\text { in the rhBMP-2 group ( } 93 \% \text { ) when compared to the ABG } \\
\text { group }(63 \%) \text {, a unique finding }\end{array}$ \\
\hline Fallucco and Carstens [24] & 2009 & $\begin{array}{l}\text { Retrospective cohort study using } \\
\text { rhBMP-2 }(n=17)\end{array}$ & $\begin{array}{l}\text { Vertical and transverse filling of maxillary cleft by new bone } \\
\text { seen with spiral CT at six months in sixteen of seventeen cleft } \\
\text { repairs }\end{array}$ \\
\hline Alonso et al. [25] & 2010 & $\begin{array}{l}\text { Randomized controlled trial } \\
\text { using rhBMP-2 }(n=16)\end{array}$ & $\begin{array}{l}\text { Average bone volume measured by CT } 5.8 \% \text { less in } \\
\text { rhBMP-2-treated group than in ABG-treated group }\end{array}$ \\
\hline
\end{tabular}

ABG: autologous bone graft; CT: computed tomography; rhBMP: recombinant human bone morphogenetic protein.

segmental mandibular bone defects in thirteen patients using a titanium mesh supplemented with either autologous bone grafts (ABGs) from the iliac crest or an osteogenic device composed of demineralized bone matrix reconstituted with bone morphogenetic proteins harvested and partially purified from allogenic bone [27]. Upon biopsy at three months, two out of the six patients treated with the osteogenic device had histologic evidence of bone formation and five out of the seven patients treated with ABGs had histologic evidence of bone formation.

A unique 2004 case report from Germany documents the use of an exogenously prepared customized mandibular bone graft grown in the latissimus dorsi muscle of the patient prior to its use for reconstruction of a large mandibular defect [28]. The graft was prepared by filling a customized titanium mesh outer scaffolding with an amalgam of hydroxyapatite blocks coated with rhBMP-7 and autologous bone marrow mesenchymal stem cells. This preparation was subsequently implanted into the patient's latissimus dorsi muscle for seven weeks to allow for vascularization, ossification, and bone remodeling within the graft prior to reconstruction of the mandible. Implantation of the graft into the latissimus dorsi effectively allowed the muscle to serve as a human bioreactor prior to subsequent free flap transfer into the mandibular defect. The patient's postoperative course was complicated by fracture of the scaffolding near the docking points of the mesh to the proximal mandible stumps. The fracture caused exposure of the implant to oral flora resulting in infection of the implant and necrosis of areas of bone inside the mandible. The necrotic areas were removed surgically and the remaining healthy bone portion of the implant remained in place in the patient until his death from a cardiac arrest fifteen months later. Radiation therapy at the location of the implant, the patient's refusal to stop smoking, and consumption of hard nut candy and heavy meals may have influenced the development of morbidities.

Two case series document the use of rhBMPs in mandibular reconstruction, one using collagen sponges containing rhBMP-2 and another using demineralized bone matrix reconstituted with rhBMP-7 [4, 29].

One of the above studies utilizing rhBMP-2 was able to demonstrate successful restoration of mandibular continuity in three out of five patients receiving rhBMP-2 implants. Investigators in this study report that four out of five patients experienced significant facial swelling far greater than would be expected in the case of autologous bone graft reconstruction [29]. Successful restoration of mandibular continuity using rhBMP-2 has also been reported by Herford et al. in case reports featuring three different patients [45, $127,129,131,132]$.

In the study by Clokie and Sándor, successful restoration of mandibular continuity was achieved in all ten patients using the rhBMP-7 reconstituted demineralized bone matrix and rigid reconstruction plates. Swelling and induration at the site of implantation were reported in all ten cases but resolved 4 weeks postoperatively [4].

Overall, these clinical cases provide strong evidence that rhBMPs are capable of inducing osteogenesis in the setting of mandibular defects, though they are not as reliable or effective as the gold standard of autologous bone grafting. A review article summarizing these clinical studies reports an overall 13.5\% failure rate of rhBMP mandibular reconstructions excluding the exogenously prepared implant described by Herford et al. [45]. 
TABLE 2: Selected clinical studies using rhBMPs for human mandibular reconstruction.

\begin{tabular}{|c|c|c|c|}
\hline Authors & Year & Description & Main findings \\
\hline Moghadam et al. [26] & 2001 & $\begin{array}{l}\text { Case report using poloxamer-based gel } \\
\text { containing BMP partially purified from } \\
\text { allogenic bone }\end{array}$ & $\begin{array}{l}\text { Successful clinical result; radiographic confirmation } \\
\text { of bone formation at } 3 \text { and } 9 \text { months; biopsy for } \\
\text { histological confirmation of bone formation at } 9 \\
\text { months }\end{array}$ \\
\hline Ferretti and Ripamonti [27] & 2002 & $\begin{array}{l}\text { Randomized controlled trial using } \\
\text { demineralized bone matrix reconstituted } \\
\text { with BMP partially purified from allogenic } \\
\text { bone }(n=13)\end{array}$ & $\begin{array}{l}\text { Biopsy at three months showed bone formation in } \\
\text { two out of six patients treated with BMP and five out } \\
\text { of seven treated with ABG }\end{array}$ \\
\hline Warnke et al. [28] & 2006 & $\begin{array}{l}\text { Case report of reconstruction with } \\
\text { exogenously prepared titanium mesh graft } \\
\text { filled with rhBMP-7-coated hydroxyapatite } \\
\text { blocks }\end{array}$ & $\begin{array}{l}\text { Successful clinical functional result achieved } \\
\text { following free flap transfer of the customized } \\
\text { mandibular graft to the maxilla following 7-week } \\
\text { incubation in the latissimus dorsi }\end{array}$ \\
\hline Clokie and Sándor [4] & 2008 & $\begin{array}{l}\text { Case series using rhBMP-7 reconstituted } \\
\text { demineralized bone matrix in ten patients }\end{array}$ & $\begin{array}{l}\text { Successful radiographic and functional restoration } \\
\text { of mandibular continuity in all } 10 \text { patients }\end{array}$ \\
\hline Carter et al. [29] & 2008 & $\begin{array}{l}\text { Case series using rhBMP-2-soaked collagen } \\
\text { sponges alone or in combination with bone } \\
\text { marrow cells and allogenic cancellous bone } \\
\text { chips; five patients, four with mandibular } \\
\text { continuity defects and one with two large } \\
\text { bone cavities in the mandible }\end{array}$ & $\begin{array}{l}\text { Restoration of mandibular defects in } 3 \text { out of } 5 \\
\text { patients assessed clinically and by radiograph; two } \\
\text { patients with failed reconstruction had mandibular } \\
\text { continuity defects }\end{array}$ \\
\hline
\end{tabular}

ABG: autologous bone graft; CT: computed tomography; rhBMP: recombinant human bone morphogenetic protein.

\section{Isolation, Purification, and Culture of Adult Mesenchymal Stem Cells}

Techniques for the identification, isolation, purification, and subculture of human bone-marrow-derived mesenchymal stem cells (BM-MSCs) have been previously established in many studies [133, 134, 134-136]. Mesenchymal stem cells derived from human bone marrow can be cultivated, cryopreserved, maintained in a progenitor state, and expanded over one-billion-fold ex vivo [133, 137]. Bone marrow mesenchymal stem cells are multipotent and capable of subsequently being driven down differentiation pathways to bone, cartilage, adipose, and connective tissue [133, 138140]. In addition to BM-MSCs, adult adipose-derived stem cells have also been shown to have osteogenic potential and have been successfully used with synthetic scaffolds to repair critical-size calvarial defects in a mouse model [141, 141-147]. Clinically, the use of osteoblast precursors may be limited by the lifespan of these cells both in culture and following implantation into patients. Strategies for immortalization of these cells, such as adenoviral gene therapy with human telomerase reverse transcriptase, have been developed and successfully used to bridge criticalsize defects in animal models; however, the potential for tumorigenesis of immortalized cell populations poses a significant risk to patients $[147,148]$. Though protocols have been described for isolation of these cells via collection from marrow and isolation of MSCs by adherence to culture plates in various media, the process is not standardized and may not currently be optimized $[135,138,139,149]$. Despite the lack of a definitive protocol for isolation and expansion of human populations of osteoblast precursors, these multipotent stem cells provide a fertile ground for the application of bone morphogenetic proteins for use in developing bone-forming tissue ex vivo.

\section{Paradigm for Osteogenic Differentiation of MSCs}

The tissue engineering strategy of ex vivo isolation, expansion, and differentiation of adult-derived mesenchymal stem cells by exposure to BMPs is a promising alternative to autografts, allografts, and alloplastic bone substrate materials in craniofacial repair. The transfer of these personalized and modified osteoprogenitor cells to a critical-size osseous defect has high therapeutic potential for repair of craniofacial deformities caused by trauma, tumor, infection, or congenital disease in both adult and pediatric patients. A significant advantage in the use of mesenchymal stem cells derived from a patient's own tissues is that these modified cells can be used without the threat of many of the potential sources of complication and morbidity associated with allografts and alloplastic materials, for example, the morbidity associated with insufficient biocompatibility of alloplastic materials and the sterility of alloplastic materials and allografts can be largely avoided with the use of mesenchymal-stemcell-derived osteoblasts. Personalized ex vivo differentiated osteoblasts, unlike alloplastic materials, can also fulfill the need for a stable biological substrate that can grow and adapt over time, a crucial feature for reconstruction in both adults and children.

Furthermore, implantation of osteoblastic cells differentiated ex vivo may provide a substrate superior to direct implantation of BMPs or BMPs delivered by adenoviruses. Exogenous applications of BMPs can cause many clinical morbidities including but not limited to the persistent 
formation of ectopic bone nodules, highly accelerated, unregulated bone growth that outstrips the ability of surrounding tissues to provide vascular and nutritive support and localized inflammatory reactions [32, 33, 48, 128]. Additionally, defects and loss of control in the differentiation of mesenchymal stem cells have been shown to be responsible for the formation of human bone and soft tissue cancers such as osteosarcoma $[150,151]$. Unfortunately, the populations of cells exposed to exogenous BMPs cannot be monitored in vivo for the development of neoplasia. The danger of tumorigenesis is present with the application of recombinant protein and virus; however, it is especially apparent in the setting of gene therapy where the dose of BMP delivered is not tunable (i.e., there is no "off" switch). Thus, a significant obstacle to therapeutic application of exogenously delivered BMPs is the lack of control of tumorigenesis of the exposed cell population. In light of these dangers, exogenous BMP therapy should be approached with significant caution.

The adverse outcomes associated with direct exogenous or adenoviral delivery of BMPs to bony defects could be prevented by the application of personalized bone-forming cells. A significant advantage of ex vivo tissue engineering strategies is the control of tumorigenesis of the expanded cell population; expanded populations of osteoblastic cells differentiated from MSCs could be tested to ensure that cancerous cells are not transferred back to the patient. Strategies incorporating MSCs for use in craniofacial repair are not exempt from difficulty, however, as current techniques for isolation and expansion of cells are expensive and time consuming. In addition, the application of ex vivo engineered cell populations and bone tissue may be limited by the potentially limited life span of mesenchymal stem cells and osteoblastic cells in vivo. Further research into the improvement of these techniques may make the use of personalized stem cells an efficient and feasible approach for patients facing craniofacial reconstruction in the future.

\section{Conflict of Interests}

The authors declare no conflict of interests.

\section{Acknowledgment}

The authors apologize to the investigators whose original work was not cited due to space constraints.

\section{References}

[1] D. J. Verret, Y. Ducic, L. Oxford, and J. Smith, "Hydroxyapatite cement in craniofacial reconstruction," Otolaryngology, vol. 133, no. 6, pp. 897-899, 2005.

[2] S. Touzet, J. Ferri, T. Wojcik, and G. Raoul, "Complications of calvarial bone harvesting for maxillofacial reconstructions," Journal of Craniofacial Surgery, vol. 22, no. 1, pp. 178-181, 2011.

[3] L. A. Whitaker, I. R. Munro, and K. E. Salyer, "Combined report of problems and complications in 793 craniofacial operations," Plastic and Reconstructive Surgery, vol. 64, no. 2, pp. 198-203, 1979.
[4] C. M. L. Clokie and G. K. B. Sándor, "Reconstruction of 10 major mandibular defects using bioimplants containing BMP-7," Journal of the Canadian Dental Association, vol. 74, no. 1, pp. 67-72, 2008.

[5] J. G. Seiler 3rd and J. Johnson, "Iliac crest autogenous bone grafting: donor site complications," Journal of the Southern Orthopaedic Association, vol. 9, no. 2, pp. 91-97, 2000.

[6] M. A. Hoard, T. J. Bill, and R. L. Campbell, "Reduction in morbidity after iliac crest bone harvesting: the concept of preemptive analgesia," Journal of Craniofacial Surgery, vol. 9, no. 5, pp. 448-451, 1998.

[7] P. Tessier, H. Kawamoto, D. Matthews et al., "Autogenous bone grafts and bone substitutes-tools and techniques: I. A 20,000-case experience in maxillofacial and craniofacial surgery," Plastic and Reconstructive Surgery, vol. 116, no. 5, supplement, pp. 6S-24S, 2005.

[8] P. Tessier, H. Kawamoto, D. Matthews et al., "Taking bone grafts from the anterior and posterior ilium-tools and techniques: II. A 6800-case experience in maxillofacial and craniofacial surgery," Plastic and Reconstructive Surgery, vol. 116, no. 5, supplement, pp. 25S-37S, 2005.

[9] P. Tessier, H. Kawamoto, D. Matthews et al., "Taking long rib grafts for facial reconstruction-tools and techniques: III. A 2900-case experience in maxillofacial and craniofacial surgery," Plastic and Reconstructive Surgery, vol. 116, no. 5, supplement, pp. 38S-46S, 2005.

[10] P. Tessier, H. Kawamoto, D. Matthews et al., "Taking tibial grafts in the diaphysis and upper epiphysis-Tools and techniques: IV. A 650-case experience in maxillofacial and craniofacial surgery," Plastic and Reconstructive Surgery, vol. 116, no. 5, supplement, pp. 47S-53S, 2005.

[11] P. Tessier, H. Kawamoto, J. Posnick, Y. Raulo, J. F. Tulasne, and S. A. Wolfe, "Taking calvarial grafts, either split in situ or splitting of the parietal bone flap ex vivo-tools and techniques: V. A 9650-case experience in craniofacial and maxillofacial surgery," Plastic and Reconstructive Surgery, vol. 116, no. 5, supplement, pp. 54S-71S, 2005.

[12] P. Tessier, H. Kawamoto, J. Posnick, Y. Raulo, J. F. Tulasne, and S. A. Wolfe, "Complications of harvesting autogenous bone grafts: a group experience of 20,000 cases," Plastic and Reconstructive Surgery, vol. 116, no. 5, supplement, pp. 72S73S, 2005.

[13] P. Tessier, H. Kawamoto, J. Posnick, Y. Raulo, J. F. Tulasne, and S. A. Wolfe, "Taking calvarial grafts—-tools and techniques: VI. The splitting of a parietal bone "flap"', Plastic and Reconstructive Surgery, vol. 116, no. 5, supplement, pp. 74S88S, 2005.

[14] M. J. Citardi and C. D. Friedman, "Nonvascularized autogenous bone grafts for craniofacial skeletal augmentation and replacement," Otolaryngologic Clinics of North America, vol. 27, no. 5, pp. 891-910, 1994.

[15] D. M. Smith, A. M. Afifi, G. M. Cooper, M. P. Mooney, K. G. Marra, and J. E. Losee, "BMP-2YBased repair of largescale calvarial defects in an experimental model: regenerative surgery in cranioplasty," Journal of Craniofacial Surgery, vol. 19, no. 5, pp. 1315-1322, 2008.

[16] D. M. Smith, G. M. Cooper, A. M. Afifi et al., "Regenerative surgery in cranioplasty revisited: the role of adipose-derived stem cells and BMP-2," Plastic and Reconstructive Surgery, vol. 128, no. 5, pp. 1053-1060, 2011.

[17] D. C. Wan, O. O. Aalami, Z. Wang et al., "Differential gene expression between juvenile and adult dura mater: a window into what genes play a role in the regeneration of 
membranous bone," Plastic and Reconstructive Surgery, vol. 118, no. 4, pp. 851-861, 2006.

[18] D. M. Smith, G. M. Cooper, M. P. Mooney, K. G. Marra, and J. E. Losee, "Bone morphogenetic protein 2 therapy for craniofacial surgery," Journal of Craniofacial Surgery, vol. 19, no. 5, pp. 1244-1259, 2008.

[19] S. D. Moss, E. Joganic, K. H. Manwaring, and S. P. Beals, "Transplanted demineralized bone graft in cranial reconstructive surgery," Pediatric Neurosurgery, vol. 23, no. 4, pp. 199-205, 1995.

[20] M. Chin, T. Ng, W. K. Tom, and M. Carstens, "Repair of alveolar clefts with recombinant human bone morphogenetic protein (rhBMP-2) in patients with clefts," Journal of Craniofacial Surgery, vol. 16, no. 5, pp. 778-789, 2005.

[21] M. H. Carstens, M. Chin, T. Ng, and W. K. Tom, "Reconstruction of \#7 facial cleft with distraction-assisted in situ osteogenesis (DISO): role of recombinant human bone morphogenetic protein-2 with helistat-activated collagen implant," Journal of Craniofacial Surgery, vol. 16, no. 6, pp. 1023-1032, 2005.

[22] A. S. Herford, P. J. Boyne, R. Rawson, and R. P. Williams, "Bone morphogenetic protein-induced repair of the premaxillary cleft," Journal of Oral and Maxillofacial Surgery, vol. 65, no. 11, pp. 2136-2141, 2007.

[23] B. P. Dickinson, R. K. Ashley, K. L. Wasson et al., "Reduced morbidity and improved healing with bone morphogenic protein-2 in older patients with alveolar cleft defects," Plastic and Reconstructive Surgery, vol. 121, no. 1, pp. 209-217, 2008.

[24] M. A. Fallucco and M. H. Carstens, "Primary reconstruction of alveolar clefts using recombinant human bone morphogenic protein-2: clinical and radiographic outcomes," Journal of Craniofacial Surgery, vol. 20, no. 8, supplement, pp. 1759-1764, 2009.

[25] N. Alonso, D. Y. S. Tanikawa, R. D. S. Freitas, L. Canan, T. O. Ozawa, and D. L. Rocha, "Evaluation of maxillary alveolar reconstruction using a resorbable collagen sponge with recombinant human bone morphogenetic protein-2 in cleft lip and palate patients," Tissue Engineering C, vol. 16, no. 5, pp. 1183-1189, 2010.

[26] H. G. Moghadam, M. R. Urist, G. K. B. Sandor, and C. M. L. Clokie, "Successful mandibular reconstruction using a BMP bioimplant," Journal of Craniofacial Surgery, vol. 12, no. 2, pp. 119-127, 2001.

[27] C. Ferretti and U. Ripamonti, "Human segmental mandibular defects treated with naturally derived bone morphogenetic proteins," Journal of Craniofacial Surgery, vol. 13, no. 3, pp. 434-444, 2002.

[28] P. H. Warnke, J. Wiltfang, I. Springer et al., "Man as living bioreactor: fate of an exogenously prepared customized tissue-engineered mandible," Biomaterials, vol. 27, no. 17, pp. 3163-3167, 2006.

[29] T. G. Carter, P. S. Brar, A. Tolas, and O. R. Beirne, "Off-label use of recombinant human bone morphogenetic protein-2 (rhBMP-2) for reconstruction of mandibular bone defects in humans," Journal of Oral and Maxillofacial Surgery, vol. 66, no. 7, pp. 1417-1425, 2008.

[30] R. Tieghi, G. Consorti, and L. C. Clauser, "Contouring of the forehead irregularities (washboard effect) with bone biomaterial," Journal of Craniofacial Surgery, vol. 23, no. 3, pp. 932-934, 2012.

[31] S. Ehrmantraut, A. Naumann, V. Willnecker et al., "Vitalization of porous polyethylene (Medpor) with chondrocytes promotes early implant vascularization and incorporation into the host tissue," Tissue Engineering A, vol. 18, no. 15-16, pp. 1562-1572, 2012.

[32] M. P. Bostrom and D. A. Seigerman, "The clinical use of allografts, demineralized bone matrices, synthetic bone graft substitutes and osteoinductive growth factors: a survey study," HSS Journal, vol. 1, no. 1, pp. 9-18, 2005.

[33] A. Kolk, J. Handschel, W. Drescher et al., "Current trends and future perspectives of bone substitute materials-from space holders to innovative biomaterials," Journal of CranioMaxillofacial Surgery. In press.

[34] R. K. Wong, B. M. Gandolfi, H. St-Hilaire, M. W. Wise, and M. Moses, "Complications of hydroxyapatite bone cement in secondary pediatric craniofacial reconstruction," Journal of Craniofacial Surgery, vol. 22, no. 1, pp. 247-251, 2011.

[35] L. Chen, W. Jiang, J. Huang et al., "Insulin-like growth factor 2 (IGF-2) potentiates BMP-9-induced osteogenic differentiation and bone formation," Journal of Bone and Mineral Research, vol. 25, no. 11, pp. 2447-2459, 2010.

[36] J. Luo, M. Tang, J. Huang et al., “TGF $\beta /$ BMP type I receptors ALK1 and ALK2 are essential for BMP9-induced osteogenic signaling in mesenchymal stem cells," Journal of Biological Chemistry, vol. 285, no. 38, pp. 29588-29598, 2010.

[37] Q. Kang, W. X. Song, Q. Luo et al., "A Comprehensive analysis of the dual roles of BMPs in regulating adipogenic and osteogenic differentiation of mesenchymal progenitor cells," Stem Cells and Development, vol. 18, no. 4, pp. 545-558, 2009.

[38] K. A. Sharff, W. X. Song, X. Luo et al., "Heyl basic helixloop-helix protein plays an important role in mediating BMP9-induced osteogenic differentiation of mesenchymal progenitor cells," Journal of Biological Chemistry, vol. 284, no. 1, pp. 649-659, 2009.

[39] N. Tang, W. X. Song, J. Luo et al., "BMP-9-induced osteogenic differentiation of mesenchymal progenitors requires functional canonical Wnt/ $\beta$-catenin signalling," Journal of Cellular and Molecular Medicine, vol. 13, no. 8 B, pp. 24482464, 2009.

[40] Q. Kang, M. H. Sun, H. Cheng et al., "Characterization of the distinct orthotopic bone-forming activity of 14 BMPs using recombinant adenovirus-mediated gene delivery," Gene Therapy, vol. 11, no. 17, pp. 1312-1320, 2004.

[41] H. Cheng, W. Jiang, F. M. Phillips et al., "Osteogenic activity of the fourteen types of human bone morphogenetic proteins (BMPs)," Journal of Bone and Joint Surgery A, vol. 85, no. 8, pp. 1544-1552, 2003.

[42] Y. Peng, Q. Kang, H. Cheng et al., "Transcriptional characterization of bone morphogenetic proteins (BMPs)-mediated osteogenic signaling," Journal of Cellular Biochemistry, vol. 90, no. 6, pp. 1149-1165, 2003.

[43] T. C. He, "Distinct osteogenic activity of BMPs and their orthopaedic applications," Journal of Musculoskeletal Neuronal Interactions, vol. 5, no. 4, pp. 363-366, 2005.

[44] A. N. Glied and R. A. Kraut, "Off-label use of rhBMP-2 for reconstruction of critical-sized mandibular defects," The New York State Dental Journal, vol. 76, no. 4, pp. 32-35, 2010.

[45] A. S. Herford, E. Stoffella, and R. Tandon, "Reconstruction of mandibular defects using bone morphogenic protein: can growth factors replace the need for autologous bone grafts? A systematic review of the literature," Plastic Surgery International, vol. 2011, Article ID 165824, 7 pages, 2011.

[46] K. B. Lee, S. S. Murray, C. E. Taghavi et al., "Bone morphogenetic protein-binding peptide reduces the inflammatory response to recombinant human bone morphogenetic protein-2 and recombinant human bone morphogenetic 
protein-7 in a rodent model of soft-tissue inflammation," Spine Journal, vol. 11, no. 6, pp. 568-576, 2011.

[47] K.-B. Lee, C. E. Taghavi, S. S. Murray, K.-J. Song, G. Keorochana, and J. C. Wang, "BMP induced inflammation: a comparison of rhBMP-7 and rhBMP-2," Journal of Orthopaedic Research, vol. 30, no. 12, pp. 1985-1994, 2012.

[48] M. M. Shah, M. D. Smyth, and A. S. Woo, "Adverse facial edema associated with off-label use of recombinant human bone morphogenetic protein-2 in cranial reconstruction for craniosynostosis: case report," Journal of Neurosurgery, vol. 1, no. 3, pp. 255-257, 2008.

[49] B. Perri, M. Cooper, C. Lauryssen, and N. Anand, "Adverse swelling associated with use of rh-BMP-2 in anterior cervical discectomy and fusion: a case study," Spine Journal, vol. 7, no. 2, pp. 235-239, 2007.

[50] L. M. Tumialan and G. E. Rodts, "Adverse swelling associated with use of rh-BMP-2 in anterior cervical discectomy and fusion," Spine Journal, vol. 7, no. 4, pp. 509-510, 2007.

[51] M. Laursen, K. Høy, E. S. Hansen, J. Gelineck, F. B. Christensen, and C. E. Bünger, "Recombinant bone morphogenetic protein-7 as an intracorporal bone growth stimulator in unstable thoracolumbar burst fractures in humans: preliminary results," European Spine Journal, vol. 8, no. 6, pp. 485490, 1999.

[52] C. Jeppsson and P. Aspenberg, "BMP-2 can inhibit bone healing: bone-chamber study in rabbits," Acta Orthopaedica, vol. 67, no. 6, pp. 589-592, 1996.

[53] L. Attisano and J. L. Wrana, "Signal transduction by the TGF$\beta$ superfamily," Science, vol. 296, no. 5573, pp. 1646-1647, 2002.

[54] G. C. Blobe, W. P. Schiemann, and H. F. Lodish, "Role of transforming growth factor $\beta$ in human disease," New England Journal of Medicine, vol. 342, no. 18, pp. 1350-1358, 2000.

[55] R. Derynck and X. H. Feng, "TGF-beta receptor signaling," Biochimica et Biophysica Acta, vol. 1333, no. 2, pp. F105F150, 1997.

[56] J. Massagué and Y.-G. Chen, "Controlling TGF- $\beta$ signaling," Genes and Development, vol. 14, no. 6, pp. 627-644, 2000.

[57] J. Massague, "The transforming growth factor- $\beta$ family," Annual Review of Cell Biology, vol. 6, pp. 597-641, 1990.

[58] S. Ross and C. S. Hill, "How the Smads regulate transcription," International Journal of Biochemistry and Cell Biology, vol. 40, no. 3, pp. 383-408, 2008.

[59] B. R. Olsen, A. M. Reginato, and W. Wang, "Bone development," Annual Review of Cell and Developmental Biology, vol. 16, pp. 191-220, 2000.

[60] T. R. S. Amand, Y. Zhang, E. V. Semina et al., "Antagonistic signals between BMP4 and FGF8 define the expression of Pitx1 and Pitx2 in mouse tooth-forming anlage," Developmental Biology, vol. 217, no. 2, pp. 323-332, 2000.

[61] E. Ozkaynak, P. N. J. Schnegelsberg, D. F. Jin et al., "Osteogenic protein-2. A new member of the transforming growth factor $\beta$ superfamily expressed early in embryogenesis," Journal of Biological Chemistry, vol. 267, no. 35, pp. 2522025227, 1992.

[62] J. M. Wozney, V. Rosen, A. J. Celeste et al., "Novel regulators of bone formation: molecular clones and activities," Science, vol. 242, no. 4885, pp. 1528-1534, 1988.

[63] J. O. Hollinger, J. M. Schmitt, D. C. Buck et al., "Recombinant human bone morphogenetic protein-2 and collagen for bone regeneration," Journal of Biomedical Materials Research, vol. 43, no. 4, pp. 356-364, 1998.
[64] R. G. Hammonds, R. Schwall, A. Dudley et al., "Boneinducing activity of mature BMP- $2 \mathrm{~b}$ produced from a hybrid BMP-2a/2b precursor," Molecular Endocrinology, vol. 5, no. 1, pp. 149-155, 1991.

[65] E. A. Wang, V. Rosen, J. S. D’Alessandro et al., "Recombinant human bone morphogenetic protein induces bone formation," Proceedings of the National Academy of Sciences of the United States of America, vol. 87, no. 6, pp. 2220-2224, 1990.

[66] M. R. Urist, "Bone: formation by autoinduction," Science, vol. 150, no. 3698, pp. 893-899, 1965.

[67] B. L. M. Hogan, "Bone morphogenetic proteins: multifunctional regulators of vertebrate development," Genes and Development, vol. 10, no. 13, pp. 1580-1594, 1996.

[68] C. H. Heldin, K. Miyazono, and P. Ten Dijke, "TGF- $\beta$ signalling from cell membrane to nucleus through SMAD proteins," Nature, vol. 390, no. 6659, pp. 465-471, 1997.

[69] J. Massague, "TGF-beta signal transduction," Annual Review of Biochemistry, vol. 67, pp. 753-791, 1998.

[70] J. Massagué and F. Weis-Garcia, "Serine/threonine kinase receptors: mediators of transforming growth factor beta family signals," Cancer Surveys, vol. 27, pp. 41-64, 1996.

[71] Y. Shi and J. Massagué, "Mechanisms of TGF- $\beta$ signaling from cell membrane to the nucleus," Cell, vol. 113, no. 6, pp. 685-700, 2003.

[72] H. Yamashita, P. Ten Dijke, C. H. Heldin, and K. Miyazono, "Bone morphogenetic protein receptors," Bone, vol. 19, no. 6, pp. 569-574, 1996.

[73] D. Chen, M. Zhao, and G. R. Mundy, "Bone morphogenetic proteins," Growth Factors, vol. 22, no. 4, pp. 233-241, 2004.

[74] S. Itoh, F. Itoh, M. J. Goumans, and P. T. Dijke, "Signaling of transforming growth factor- $\beta$ family members through Smad proteins," European Journal of Biochemistry, vol. 267, no. 24, pp. 6954-6967, 2000.

[75] L. Attisano and J. L. Wrana, "Smads as transcriptional comodulators," Current Opinion in Cell Biology, vol. 12, no. 2, pp. 235-243, 2000.

[76] A. Javed, F. Afzal, J. S. Bae et al., "Specific residues of RUNX2 are obligatory for formation of BMP2-induced RUNX2SMAD complex to promote osteoblast differentiation," Cells Tissues Organs, vol. 189, no. 1-4, pp. 133-137, 2008.

[77] K. S. Lee, H. J. Kim, Q. L. Li et al., "Runx2 is a common target of transforming growth factor $\beta 1$ and bone morphogenetic protein 2, and cooperation between Runx2 and Smad5 induces osteoblast-specific gene expression in the pluripotent mesenchymal precursor cell line C2C12," Molecular and Cellular Biology, vol. 20, no. 23, pp. 8783-8792, 2000.

[78] M. Phimphilai, Z. Zhao, H. Boules, H. Roca, and R. T. Franceschi, "BMP signaling is required for RUNX2dependent induction of the osteoblast phenotype," Journal of Bone and Mineral Research, vol. 21, no. 4, pp. 637-646, 2006.

[79] Y. W. Zhang, N. Yasui, K. Ito et al., "A RUNX2/PEBP2 $\alpha$ A/ CBFA1 mutation displaying impaired transactivation and Smad interaction in cleidocranial dysplasia," Proceedings of the National Academy of Sciences of the United States of America, vol. 97, no. 19, pp. 10549-10554, 2000.

[80] K. Miyazono, P. Ten Dijke, and C. H. Heldin, "TGF- $\beta$ signaling by smad proteins," Advances in Immunology, vol. 75, pp. 115-157, 2000.

[81] P. T. Dijke, M. J. Goumans, F. Itoh, and S. Itoh, "Regulation of cell proliferation by Smad proteins," Journal of Cellular Physiology, vol. 191, no. 1, pp. 1-16, 2002.

[82] K. Miyazono, P. Ten Dijke, and C. H. Heldin, "TGF- $\beta$ signaling by Smad proteins," Advances in Immunology, vol. 75, pp. $115-157,2000$. 
[83] J. L. Wrana, "Regulation of Smad activity," Cell, vol. 100, no. 2, pp. 189-192, 2000.

[84] G. Chen, C. Deng, and Y.-P. Li, "TGF- $\beta$ and BMP signaling in osteoblast differentiation and bone formation," International Journal of Biological Sciences, vol. 8, no. 2, pp. 272-288, 2012.

[85] K. S. Lee, S. H. Hong, and S. C. Bae, "Both the Smad and p38 MAPK pathways play a crucial role in Runx2 expression following induction by transforming growth factor- $\beta$ and bone morphogenetic protein," Oncogene, vol. 21, no. 47, pp. 7156-7163, 2002.

[86] R. Nishimura, K. Hata, T. Matsubara, M. Wakabayashi, and T. Yoneda, "Regulation of bone and cartilage development by network between BMP signalling and transcription factors," Journal of Biochemistry, vol. 151, no. 3, pp. 247-254, 2012.

[87] G. Luther, E. R. Wagner, G. Zhu et al., "BMP-9 induced osteogenic differentiation of mesenchymal stem cells: molecular mechanism and therapeutic potential," Current Gene Therapy, vol. 11, no. 3, pp. 229-240, 2011.

[88] J. Luo, M. H. Sun, Q. Kang et al., "Gene therapy for bone regeneration," Current Gene Therapy, vol. 5, no. 2, pp. 167179, 2005.

[89] H. H. Luu, W. X. Song, X. Luo et al., "Distinct roles of bone morphogenetic proteins in osteogenic differentiation of mesenchymal stem cells," Journal of Orthopaedic Research, vol. 25, no. 5, pp. 665-677, 2007.

[90] T. Reya and H. Clevers, "Wnt signalling in stem cells and cancer," Nature, vol. 434, no. 7035, pp. 843-850, 2005.

[91] J. H. Jonason, G. Xiao, M. Zhang, L. Xing, and D. Chen, "Post-translational regulation of Runx2 in bone and cartilage," Journal of Dental Research, vol. 88, no. 8, pp. 693-703, 2009.

[92] T. Komori, H. Yagi, S. Nomura et al., "Targeted disruption of Cbfa1 results in a complete lack of bone formation owing to maturational arrest of osteoblasts," Cell, vol. 89, no. 5, pp. 755-764, 1997.

[93] F. Otto, A. P. Thornell, T. Crompton et al., "Cbfa1, a candidate gene for cleidocranial dysplasia syndrome, is essential for osteoblast differentiation and bone development," Cell, vol. 89, no. 5, pp. 765-771, 1997.

[94] H. Kobayashi, Y. H. Gao, C. Ueta, A. Yamaguchi, and T. Komori, "Multilineage differentiation of Cbfa1-deficient calvarial cells in vitro," Biochemical and Biophysical Research Communications, vol. 273, no. 2, pp. 630-636, 2000.

[95] C. F. Lai and S. L. Cheng, "Signal transductions induced by bone morphogenetic protein-2 and transforming growth factor- $\beta$ in normal human osteoblastic cells," Journal of Biological Chemistry, vol. 277, no. 18, pp. 15514-15522, 2002.

[96] N. Takahashi, K. Maeda, A. Ishihara, S. Uehara, and Y. Kobayashi, "Regulatory mechanism of osteoclastogenesis by RANKL and Wnt signals," Frontiers in Bioscience, vol. 16, no. 1, pp. 21-30, 2011.

[97] F. Kugimiya, H. Kawaguchi, S. Kamekura et al., "Involvement of endogenous bone morphogenetic protein (BMP) 2 and BMP6 in bone formation," Journal of Biological Chemistry, vol. 280, no. 42, pp. 35704-35712, 2005.

[98] X. B. Wu, Y. Li, A. Schneider et al., "Impaired osteoblastic differentiation, reduced bone formation, and severe osteoporosis in noggin-overexpressing mice," Journal of Clinical Investigation, vol. 112, no. 6, pp. 924-934, 2003.

[99] E. Gazzerro, R. C. Pereira, V. Jorgetti, S. Olson, A. N. Economides, and E. Canalis, "Skeletal overexpression of gremlin impairs bone formation and causes osteopenia," Endocrinology, vol. 146, no. 2, pp. 655-665, 2005.
[100] R. D. Devlin, Z. Du, R. C. Pereira et al., "Skeletal overexpression of noggin results in osteopenia and reduced bone formation," Endocrinology, vol. 144, no. 5, pp. 1972-1978, 2003.

[101] K. Tsuji, A. Bandyopadhyay, B. D. Harfe et al., "BMP2 activity, although dispensable for bone formation, is required for the initiation of fracture healing," Nature Genetics, vol. 38, no. 12, pp. 1424-1429, 2006.

[102] R. D. Farhadieh, R. Dickinson, Y. Yu, M. P. Gianoutsos, and W. R. Walsh, "The role of transforming growth factor-beta, insulin-like growth factor I, and basic fibroblast growth factor in distraction osteogenesis of the mandible," Journal of Craniofacial Surgery, vol. 10, no. 1, pp. 80-86, 1999.

[103] R. D. Farhadieh, M. P. Gianoutsos, Y. Yu, and W. R. Walsh, "The role of bone morphogenetic proteins BMP-2 and BMP4 and their related postreceptor signaling system (Smads) in distraction osteogenesis of the mandible," The Journal of Craniofacial Surgery, vol. 15, no. 5, pp. 714-718, 2004.

[104] A. Khanal, I. Yoshioka, K. Tominaga, N. Furuta, M. Habu, and J. Fukuda, "The BMP signaling and its Smads in mandibular distraction osteogenesis," Oral Diseases, vol. 14, no. 4, pp. 347-355, 2008.

[105] T. C. He, S. Zhou, L. T. Da Costa, J. Yu, K. W. Kinzler, and B. Vogelstein, "A simplified system for generating recombinant adenoviruses," Proceedings of the National Academy of Sciences of the United States of America, vol. 95, no. 5, pp. 2509-2514, 1998.

[106] M. E. Bahamonde and K. M. Lyons, "BMP3: to be or not to be a BMP," Journal of Bone and Joint Surgery A, vol. 83, no. 1, pp. S56-S62, 2001.

[107] Y. Peng, Q. Kang, Q. Luo et al., "Inhibitor of DNA binding/differentiation helix-loop-helix proteins mediate bone morphogenetic protein-induced osteoblast differentiation of mesenchymal stem cells," Journal of Biological Chemistry, vol. 279, no. 31, pp. 32941-32949, 2004

[108] J. Nickel, M. K. Dreyer, T. Kirsch, and W. Sebald, "The crystal structure of the BMP-2:BMPR-IA complex and the generation of BMP-2 antagonists," Journal of Bone and Joint Surgery A, vol. 83, supplement 1, pp. S7-S14, 2001.

[109] M. A. Brown, Q. Zhao, K. A. Baker et al., "Crystal structure of BMP-9 and functional interactions with pro-region and receptors," Journal of Biological Chemistry, vol. 280, no. 26, pp. 25111-25118, 2005.

[110] A. H. Hassanein, R. A. Couto, K. C. Kurek, G. F. Rogers, J. B. Mulliken, and A. K. Greene, "Experimental comparison of cranial particulate bone graft, rhBMP-2, and split cranial bone graft for inlay cranioplasty," The Cleft Palate-Craniofacial Journal. In press.

[111] C. R. Kinsella, J. J. Cray, D. M. Smith et al., "Novel model of calvarial defect in an infected unfavorable wound: reconstruction with rhBMP-2. part II," Journal of Craniofacial Surgery, vol. 23, no. 2, pp. 410-414, 2012.

[112] G. E. Decesare, G. M. Cooper, D. M. Smith et al., "Novel animal model of calvarial defect in an infected unfavorable wound: reconstruction with rhBMP-2," Plastic and Reconstructive Surgery, vol. 127, no. 2, pp. 588-594, 2011.

[113] J. Li, J. Hong, Q. Zheng et al., "Repair of rat cranial bone defects with nHAC/PLLA and BMP-2-related peptide or rhBMP-2," Journal of Orthopaedic Research, vol. 29, no. 11, pp. 1745-1752, 2011.

[114] T. Aghaloo, C. M. Cowan, X. Zhang et al., "The effect of NELL1 and bone morphogenetic protein- 2 on calvarial bone regeneration," Journal of Oral and Maxillofacial Surgery, vol. 68, no. 2, pp. 300-308, 2010. 
[115] J. H. Lee, C. S. Kim, K. H. Choi et al., "The induction of bone formation in rat calvarial defects and subcutaneous tissues by recombinant human BMP-2, produced in Escherichia coli," Biomaterials, vol. 31, no. 13, pp. 3512-3519, 2010.

[116] A. A. Sawyer, S. J. Song, E. Susanto et al., "The stimulation of healing within a rat calvarial defect by $\mathrm{mPCL}-\mathrm{TCP} /$ collagen scaffolds loaded with rhBMP-2," Biomaterials, vol. 30, no. 13, pp. 2479-2488, 2009.

[117] S. J. Hong, C. S. Kim, D. K. Han et al., "The effect of a fibrinfibronectin/ $\beta$-tricalcium phosphate/recombinant human bone morphogenetic protein-2 system on bone formation in rat calvarial defects," Biomaterials, vol. 27, no. 20, pp. 3810-3816, 2006.

[118] I. N. G. Springer, Y. Açil, S. Kuchenbecker et al., "Bone graft versus BMP-7 in a critical size defect-cranioplasty in a growing infant model," Bone, vol. 37, no. 4, pp. 563-569, 2005.

[119] J. P. Sheehan, J. M. Sheehan, H. Seeherman, M. Quigg, and G. A. Helm, "The safety and utility of recombinant human bone morphogenetic protein-2 for cranial procedures in a nonhuman primate model," Journal of Neurosurgery, vol. 98, no. 1, pp. 125-130, 2003.

[120] Y. Sawada, A. Hokugo, A. Nishiura et al., "A trial of alveolar cleft bone regeneration by controlled release of bone morphogenetic protein: an experimental study in rabbits," Oral Surgery, Oral Medicine, Oral Pathology, Oral Radiology and Endodontology, vol. 108, no. 6, pp. 812-820, 2009.

[121] Y. Takahashi, M. Yamamoto, K. Yamada, O. Kawakami, and Y. Tabata, "Skull bone regeneration in nonhuman primates by controlled release of bone morphogenetic protein-2 from a biodegradable hydrogel," Tissue Engineering, vol. 13, no. 2, pp. 293-300, 2007.

[122] S. Schultze-Mosgau, B. Lehner, F. Rödel et al., "Expression of bone morphogenic protein 2/4, transforming growth factor- $\beta 1$, and bone matrix protein expression in healing area between vascular tibia grafts and irradiated boneexperimental model of osteonecrosis," International Journal of Radiation Oncology Biology Physics, vol. 61, no. 4, pp. 1189-1196, 2005.

[123] I. N. G. Springer, P. Niehoff, Y. Açil et al., "BMP-2 and bFGF in an irradiated bone model," Journal of Cranio-Maxillofacial Surgery, vol. 36, no. 4, pp. 210-217, 2008.

[124] H. F. Sailer and E. Kolb, "Application of purified hone morphogenetic protein (BMP) preparations in cranio-maxillofacial surgery. Reconstruction in craniofacial malformations and post-traumatic or operative defects of the skull with lyophilized cartilage and BMP," Journal of Cranio-MaxilloFacial Surgery, vol. 22, no. 4, pp. 191-199, 1994.

[125] H. F. Sailer and E. Kolb, "Application of purified bone morphogenetic protein (BMP) in cranio- maxillo-facial surgery. BMP in compromised surgical reconstructions using titanium implants," Journal of Cranio-Maxillo-Facial Surgery, vol. 22, no. 1, pp. 2-11, 1994.

[126] M. Chao, T. Donovan, C. Sotelo, and M. H. Carstens, "In situ osteogenesis of hemimandible with rhBMP-2 in a 9-year-old boy: osteoinduction via stem cell concentration," Journal of Craniofacial Surgery, vol. 17, no. 3, pp. 405-412, 2006.

[127] A. S. Herford and P. J. Boyne, "Reconstruction of mandibular continuity defects with bone morphogenetic protein-2 (rhBMP-2)," Journal of Oral and Maxillofacial Surgery, vol. 66, no. 4, pp. 616-624, 2008.

[128] W. M. M. T. van Hout, A. B. M. van der Molen, C. C. Breugem, R. Koole, and E. M. van Cann, "Reconstruction of the alveolar cleft: can growth factor-aided tissue engineering replace autologous bone grafting? A literature review and systematic review of results obtained with bone morphogenetic protein-2," Clinical Oral Investigations, vol. 15, no. 3, pp. 297$303,2011$.

[129] A. S. Herford, "rhBMP-2 as an option for reconstructing mandibular continuity defects," Journal of Oral and Maxillofacial Surgery, vol. 67, no. 12, pp. 2679-2684, 2009.

[130] A. S. Herford and P. J. Boyne, "Reconstruction of mandibular continuity defects with bone morphogenetic protein-2 (rhBMP-2)," Journal of Oral and Maxillofacial Surgery, vol. 66, no. 4, pp. 616-624, 2008.

[131] A. S. Herford and M. Cicciù, "Recombinant human bone morphogenetic protein type 2 jaw reconstruction in patients affected by giant cell tumor," Journal of Craniofacial Surgery, vol. 21, no. 6, pp. 1970-1975, 2010.

[132] A. S. Herford, P. J. Boyne, and R. P. Williams, "Clinical applications of rhBMP-2 in maxillofacial surgery," Journal of the California Dental Association, vol. 35, no. 5, pp. 335-341, 2007.

[133] S. P. Bruder, N. Jaiswal, and S. E. Haynesworth, "Growth kinetics, self-renewal, and the osteogenic potential of purified human mesenchymal stem cells during extensive subcultivation and following cryopreservation," Journal of Cellular Biochemistry, vol. 64, no. 2, pp. 278-294, 1997.

[134] S. E. Haynesworth, M. A. Baber, and A. I. Caplan, "Cell surface antigens on human marrow-derived mesenchymal cells are detected by monoclonal antibodies," Bone, vol. 13, no. 1, pp. 69-80, 1992.

[135] S. E. Haynesworth, J. Goshima, V. M. Goldberg, and A. I. Caplan, "Characterization of cells with osteogenic potential from human marrow," Bone, vol. 13, no. 1, pp. 81-88, 1992.

[136] M. Soleimani and S. Nadri, "A protocol for isolation and culture of mesenchymal stem cells from mouse bone marrow," Nature Protocols, vol. 4, no. 1, pp. 102-106, 2009.

[137] N. Jaiswal, S. E. Haynesworth, A. I. Caplan, and S. P. Bruder, "Osteogenic differentiation of purified, culture-expanded human mesenchymal stem cells in vitro," Journal of Cellular Biochemistry, vol. 64, no. 2, pp. 295-312, 1997.

[138] D. Baksh, L. Song, and R. S. Tuan, "Adult mesenchymal stem cells: characterization, differentiation, and application in cell and gene therapy," Journal of Cellular and Molecular Medicine, vol. 8, no. 3, pp. 301-316, 2004.

[139] P. Bianco, M. Riminucci, S. Gronthos, and P. G. Robey, "Bone marrow stromal stem cells: nature, biology, and potential applications," Stem Cells, vol. 19, no. 3, pp. 180-192, 2001.

[140] M. F. Pittenger, A. M. Mackay, S. C. Beck et al., "Multilineage potential of adult human mesenchymal stem cells," Science, vol. 284, no. 5411, pp. 143-147, 1999.

[141] J. N. Beresford, J. H. Bennett, C. Devlin, P. S. Leboy, and M. E. Owen, "Evidence for an inverse relationship between the differentiation of adipocytic and osteogenic cells in rat marrow stromal cell cultures," Journal of Cell Science, vol. 102, no. 2, pp. 341-351, 1992.

[142] J. H. Bennett, C. J. Joyner, J. T. Triffitt, and M. E. Owen, "Adipocytic cells cultured from marrow have osteogenic potential," Journal of Cell Science, vol. 99, no. 1, pp. 131-139, 1991.

[143] Y. Zeng, X. Qu, H. Li et al., "MicroRNA-100 regulates osteogenic differentiation of human adipose-derived mesenchymal stem cells by targeting BMPR2," FEBS Letters, vol. 586, no. 16, pp. 2375-2381, 2012.

[144] M. Locke, V. Feisst, and P. R. Dunbar, "Concise review: human adipose-derived stem cells: separating promise from clinical need," Stem Cells, vol. 29, no. 3, pp. 404-411, 2011. 
[145] S. Wang, X. Qu, and R. C. Zhao, "Mesenchymal stem cells hold promise for regenerative medicine," Frontiers of Medicine in China, vol. 5, no. 4, pp. 372-378, 2011.

[146] C. M. Cowan, Y. Y. Shi, O. O. Aalami et al., "Adipose-derived adult stromal cells heal critical-size mouse calvarial defects," Nature Biotechnology, vol. 22, no. 5, pp. 560-567, 2004.

[147] C. Szpalski, J. Barr, M. Wetterau, P. B. Saadeh, and S. M. Warren, "Cranial bone defects: current and future strategies," Neurosurgical Focus, vol. 29, no. 6, pp. 1-11, 2010.

[148] H. Nakahara, H. Misawa, T. Hayashi et al., "Bone repair by transplantation of hTERT-immortalized human mesenchymal stem cells in mice," Transplantation, vol. 88, no. 3, pp. 346-353, 2009.

[149] S. P. Bruder, A. A. Kurth, M. Shea, W. C. Hayes, N. Jaiswal, and S. Kadiyala, "Bone regeneration by implantation of purified, culture-expanded human mesenchymal stem cells," Journal of Orthopaedic Research, vol. 16, no. 2, pp. 155-162, 1998.

[150] D. M. Steinert, L. J. Blakely, J. Salganick, and J. C. Trent, "Molecular targets in therapy for human soft-tissue and bone sarcomas," Current Oncology Reports, vol. 5, no. 4, pp. 295303, 2003.

[151] E. R. Wagner, G. Luther, G. Zhu et al., "Defective osteogenic differentiation in the development of osteosarcoma," Sarcoma, vol. 2011, Article ID 325238, 2011. 

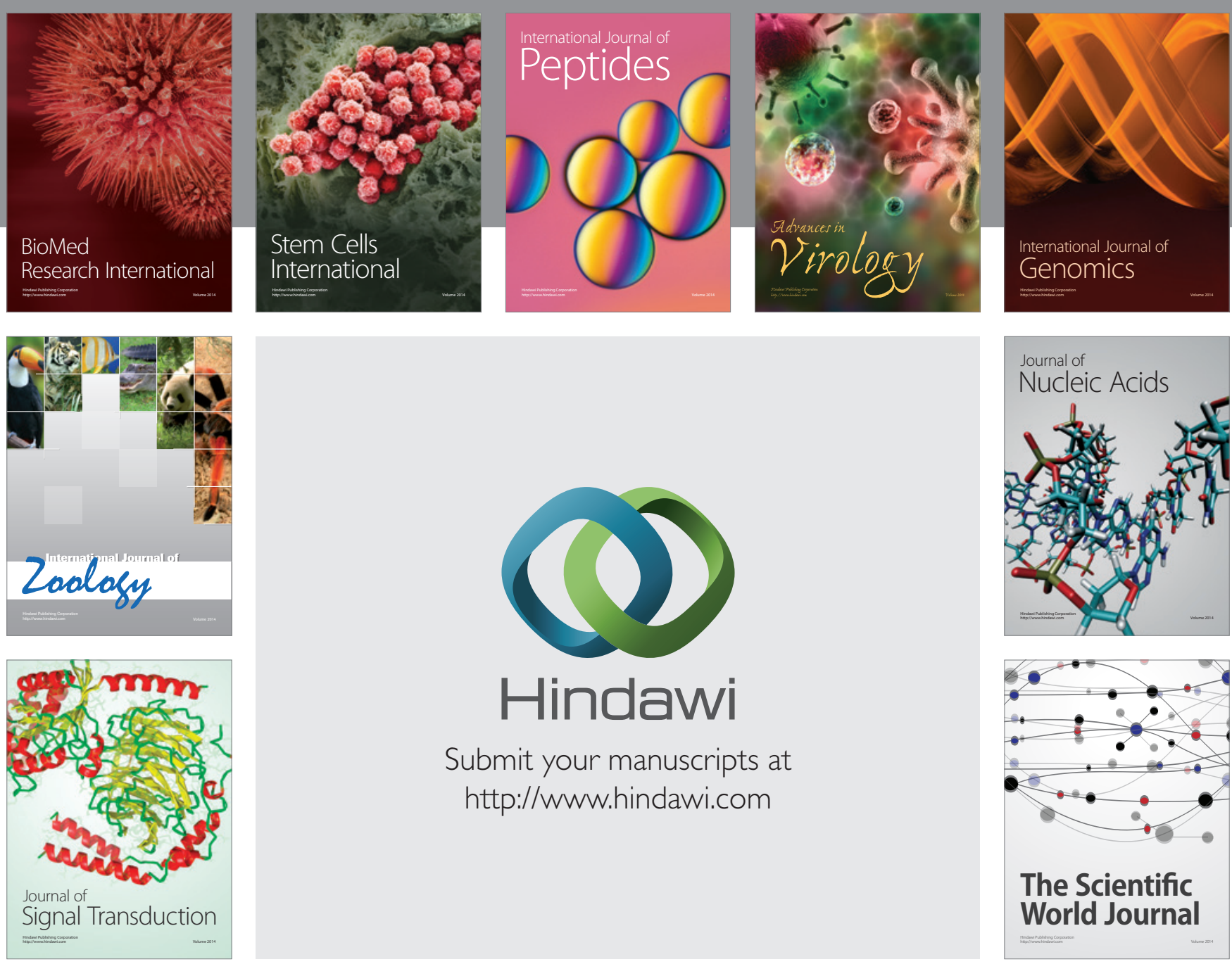

Submit your manuscripts at

http://www.hindawi.com
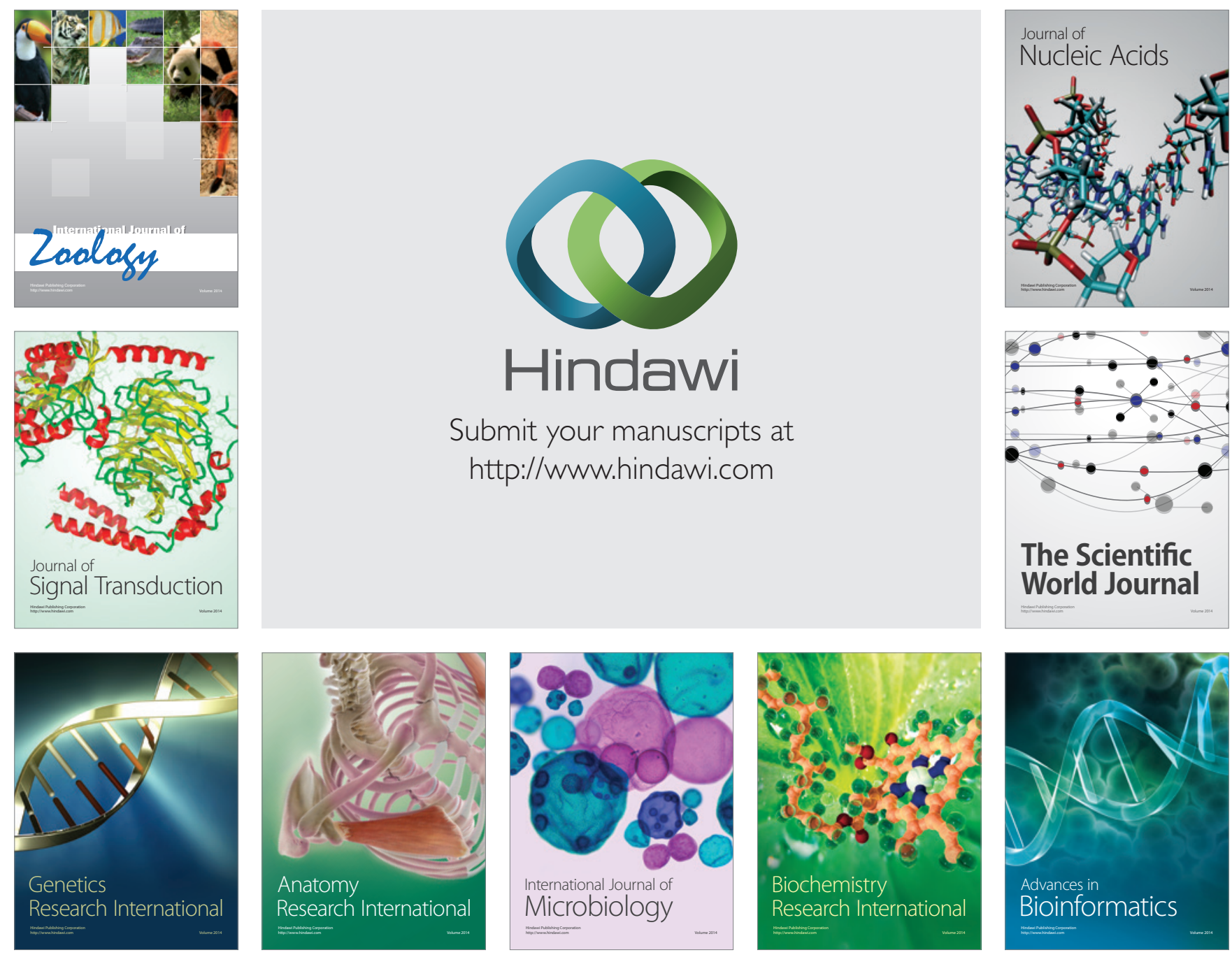

The Scientific World Journal
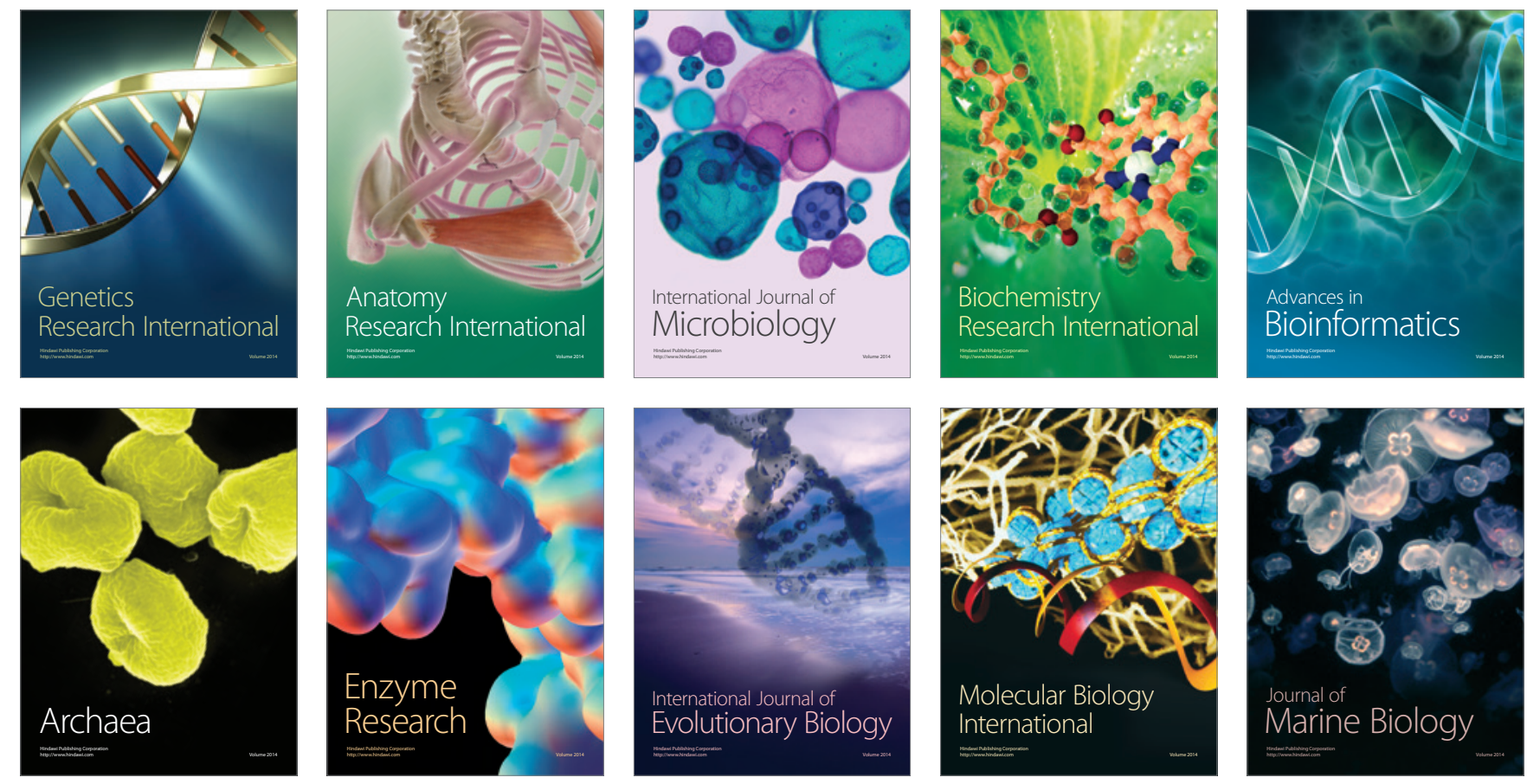